\title{
Large Lineups-The Solution to Mistaken Identifications
}

\author{
Avraham Levi* \\ Department of Israeli Police, Jerusalem, Israel
}

Submission: March 28, 2019; Published: April 22, 2019

*Corresponding author: Avraham Levi, Department of Israeli Police, Jerusalem, Israel

Abstract

Mistaken identifications continue to plague British lineups. The reason is that lineups are too small, and witnesses who choose when the suspect is innocent choose the innocent suspect too often. The solution is large lineups.

\section{Opinion}

Davies [1] outlines in detail the British experience of a century of trial and error with lineups that resulted in mistaken identifications, that persist to this day. Large lineup [2-10] decrease substantially the chance of a mistaken identification. The problem with other lineups is that they are too small. For example, the British video lineup has nine members. If the suspect is innocent yet the witness yet chooses someone, the chance that the innocent suspect will be chosen is $1 / 9=0.11$, i.e. $11 \%$. Witnesses have many reasons for choosing someone by mistake. Often, they are the victim, or they simply want to help the police.

Davies' [1] collection of cases of known mistaken identifications is one source of evidence. Valentine Pickering \& Darling [11] provide their own data and the data from Slater [12] and Wrignt, McDaid [13] which are all consistent in finding about $20 \%$ choices of a foil, which are known mistaken identifications. About $40 \%$ were identifications of the suspect, and we can assume from Davies' [1] that some of these were mistaken identifications.

As we have noted, the problem is that presently used lineups are so small. With the 48-person lineup, the chance of a witness who chooses will choose the innocent suspect is only $1 / 48=$ 0.02 , that is $2 \%$. Levi [10] found no difference in the number of correct identifications between the 48-person lineup and the British video lineup (though this finding needs to be replicated), and no difference in correct identifications between 48-person lineups and a 96-person lineup [5], which reduces mistaken identifications to $1 \%$. British police are forbidden by law to use large lineups because they are composed of photographs. As part of the "trial and error" that Davies [1] describes, Great Britain is erring in not distinguishing between small photo lineups and large ones. To reduce substantially the still existing mistaken identifications, unless some other effective means of reducing mistaken identifications is found, the British police should be allowed to use large lineups. They have a very substantial collection of mugshots from which to pick appropriate foils.

It should be noted that Levi [8] discovered that no more than twelve photos should be shown at a time to maintain reasonable levels of correct identifications. A 96-person lineup consists of 8 pages (or computer screens) and poses no difficulty for witnesses.

\section{References}

1. Davies G (2008) Eyewitness Identification and the English Courts: A Century of Trial and Error. Psychiatry Psychology and Law 1-32.

2. Levi AM (in press a) Why does the Simultaneous Lineup Produce Less Mistaken Identifications than the Showup? The 48-person Lineup. Forensic \& Genetic Sciences.

3. Levi AM (in press b) Comparing the 48-person lineup with the sequential lineup. Journal of Forensic and Crime Investigation.

4. Levi AM (in press c) Partial memory: Another reason for using large lineups? Legal and criminological psychology.

5. Levi AM (2019) Comparing 48-person lineups with a 96-person lineup. Scholarly Journal of Psychology and Behavioral Sciences 2: 131-132.

6. Levi AM (2018) The 48-person lineup. Scholarship Pres. 
7. Levi AM (2017) Comparing the English Video Lineup with the 48-Person Lineup. Universal Journal of Psychology 5(6): 239-243.

8. Levi AM (2012) Much better than the sequential lineup: a 120-person lineup. Psychology, Crime \& Law 18: 631-640.

9. Levi AM (2007) Evidence for moving to an 84-person lineup. Journal of Experimental Criminology 3: 377-391.

10. Levi AM, Menasheh D (2017) Evidence for the superiority of the 48-person lineup. Journal of Psychology and Cognition 2: 231-236.
11. Valentine T, Pickering A, Darling S (2003) Characteristics of eyewitness identification that predict the outcomes of real lineups. Applied Cognitive Psychology 17: 969-994.

12. Slater A (1994) Identification parades: A scientific evaluation. Police Award Scheme, Police Research, Group, Home Office: London.

13. Wright DB, McDaid AT (1996) Comparing system and estimator variables using data from real lineups. Applied Cognitive Psychology 10: $75-84$

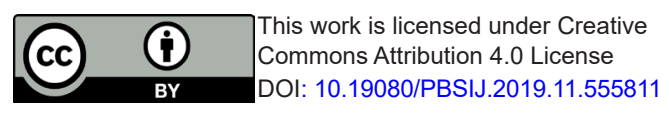

\section{Your next submission with Juniper Publishers will reach you the below assets}

- Quality Editorial service

- Swift Peer Review

- Reprints availability

- E-prints Service

- Manuscript Podcast for convenient understanding

- Global attainment for your research

- Manuscript accessibility in different formats

( Pdf, E-pub, Full Text, Audio)

- Unceasing customer service

Track the below URL for one-step submission https://juniperpublishers.com/online-submission.php 